\title{
Study on Quality Demand for Online Shop Website
}

\author{
Submitted 18/06/20, $1^{\text {st }}$ revision 14/07/20, $2^{\text {nd }}$ revision 23/08/20, accepted 30/09/20
}

\section{Yi-Chan Chung ${ }^{1}$}

\begin{abstract}
:
Purpose: This study focuses on the online shop website H and by Kano two-dimensional quality model, it obtains "the items to improve service quality" as the criteria for the website to improve the quality.

Design/Methodology/Approach: According to SERVQUAL this study classifies the measures of service quality into Responsiveness, Tangible, Reliability, Empathy and Guarantee. According to Kano model analysis, this study obtains items which highly enhance customer satisfaction and highly reduce customer dissatisfaction.

Findings: The study obtains five items which highly enhance customer satisfaction and highly reduce customer dissatisfaction: specific classification of products on the websites, immediate accomplishment of service, precise amount of bill after shopping, customer service personnel maintain certain degree of service quality, customer service personnel provide various products with consistent quality. It is suggested that the online shop website H should improve these five items in order to increase customer satisfaction and profits.

Practical implications: This study focuses on the online shop website $H$ and by Kano twodimensional quality model, it obtains "the items to improve service quality" as the criteria for the website to improve the quality.

Originality/value. This study obtains five "items to improve service quality" which increase customer satisfaction and reduce customer dissatisfaction. The website can maintain good service quality of these items to result in maximum profit.
\end{abstract}

Keywords: Online shop website, Kano model, service quality.

JEL codes:

Paper type: Research article.

\footnotetext{
${ }^{1}$ Associate Professor, Department of Business Administration, Yuanpei University of Medical Technology, Taiwan kent4321@ms19.hinet.net;
} 


\section{Introduction}

Competition in online shop website market is gradually severe. The shops should develop unique services, recognize customers' needs and enhance customer satisfaction with service quality in order to attract more customers and result in higher profits. According to SERVQUAL proposed by Parasuraman et al. (1988), measures of quality include Responsiveness, Tangible, Reliability, Empathy and Guarantee. Measurement items of service quality are based on literatures and modified upon the characteristics of the online shop website.

According to questionnaires, it obtains "attributes to improve service quality" which highly increase customer satisfaction and reduce customer dissatisfaction. The analytical result helps the online shop website to enhance quality and competitive advantages.

\section{Literature Review}

\subsection{Service Quality}

Bateson and Hoffman (2002) argued that the measurement of service quality depends on the customers' cognition after receiving the services. Parasuraman et al. (1988) introduced five dimensions of service quality, including (1) Reliability; (2) Responsiveness; (3) Guarantee; (4) Empathy; (5) Tangible. Tsiotsou (2006) suggested that service quality is the customers' general evaluation on the advantages, disadvantages, and rating of the products. According to SERVQUAL proposed by Parasuraman et al. (1988), this study classifies the measures of service quality into Responsiveness, Tangible, Reliability, Empathy and Guarantee. Measurement items of service quality are based on the questionnaires of Antony et al. (2004), Zeithaml et al. (2002), Chung and Chen (2015) and Parasuraman et al. (1988) and modified upon the characteristics of the online shop website.

\subsection{Kano Two-Dimensional Quality Model}

Kano et al. (1984) classified quality items into five categories, including Attractive Quality Element (A), One-Dimensional Quality Element (O), Must-Be Quality Element (M), Indifferent Quality Element (I), Reverse Quality Element (R). Kano Model is commonly applied to many areas and studies (Zhang and Von Dran, 2001). Kano et al. (1984) investigated customers' cognition towards the quality items and the responses include "I like it that way", "Take it for granted", "It does not matter", "Can be tolerated" and "Dislike". Matzler and Hinterhuber (1998) proposed twodimensional quality factor classification of modified Kano model, as shown in Table 1.

Matzler and Hinterhuber (1998) adopts "customer satisfaction coefficients" as the criterion to improve the quality. The formula of coefficient is shown below: 
C (1): Coefficient to increase customer satisfaction $=(A+O) /(A+O+M+I)$

$\mathrm{C}$ (2): Coefficient to reduce customer dissatisfaction $=(\mathrm{O}+\mathrm{M}) /(\mathrm{A}+\mathrm{O}+\mathrm{M}+\mathrm{I}) \times(-1)$

Where: A: Attractive Quality; O: One-Dimensional Quality; M: Must-Be Quality; I: Indifferent Quality

Table 1. Categories of two-dimensional quality elements of Matzler and Hinterhuber

\begin{tabular}{|l|l|l|l|l|l|}
\hline $\begin{array}{c}\text { Negative } \\
\text { Positive }\end{array}$ & $\begin{array}{l}\text { I like it that } \\
\text { way }\end{array}$ & $\begin{array}{l}\text { Take it for It does not } \\
\text { granted } \\
\text { matter }\end{array}$ & $\begin{array}{l}\text { Can } \\
\text { tolerated }\end{array}$ & be & Dislike \\
\hline I like it that way & Uncertain & $\begin{array}{l}\text { Attractive } \\
\text { Quality }\end{array}$ & $\begin{array}{l}\text { Attractive } \\
\text { Quality }\end{array}$ & $\begin{array}{l}\text { Attractive } \\
\text { Quality }\end{array}$ & $\begin{array}{l}\text { One- } \\
\text { Dimensional } \\
\text { Quality }\end{array}$ \\
\hline $\begin{array}{l}\text { Take it for } \\
\text { granted }\end{array}$ & $\begin{array}{l}\text { Reverse } \\
\text { Quality }\end{array}$ & $\begin{array}{l}\text { Indifferent } \\
\text { Quality }\end{array}$ & $\begin{array}{l}\text { Indifferent } \\
\text { Quality }\end{array}$ & $\begin{array}{l}\text { Indifferent } \\
\text { Quality }\end{array}$ & Must-Be Quality \\
\hline It does not matter & $\begin{array}{l}\text { Reverse } \\
\text { Quality }\end{array}$ & $\begin{array}{l}\text { Indifferent } \\
\text { Quality }\end{array}$ & $\begin{array}{l}\text { Indifferent } \\
\text { Quality }\end{array}$ & $\begin{array}{l}\text { Indifferent } \\
\text { Quality }\end{array}$ & Must-Be Quality \\
\hline Can be tolerated & $\begin{array}{l}\text { Reverse } \\
\text { Quality }\end{array}$ & $\begin{array}{l}\text { Indifferent } \\
\text { Quality }\end{array}$ & $\begin{array}{l}\text { Indifferent } \\
\text { Quality }\end{array}$ & $\begin{array}{l}\text { Indifferent } \\
\text { Quality }\end{array}$ & Must-Be Quality \\
\hline Dislike & $\begin{array}{l}\text { Reverse } \\
\text { Quality }\end{array}$ & $\begin{array}{l}\text { Reverse } \\
\text { Quality }\end{array}$ & $\begin{array}{l}\text { Reverse } \\
\text { Quality }\end{array}$ & $\begin{array}{l}\text { Reverse } \\
\text { Quality }\end{array}$ & Uncertain \\
\hline
\end{tabular}

Source: Author.

\section{Research Methodology}

According to SERVQUAL proposed by Parasuraman et al. (1988), this study classifies the measures of service quality into Responsiveness, Tangible, Reliability, Empathy and Guarantee. According to Kano model analysis, this study obtains items which highly enhance customer satisfaction and highly reduce customer dissatisfaction. Measurement items of service quality are based on the questionnaires of Antony et al. (2004), Chung and Chen (2015), Zeithaml et al. (2002) and Parasuraman et al. (1988) and modified upon the characteristics of the online shop website.

Research subjects are customers of the online shop website H. From August 1 to 31, 2020, it retrieved 45 questionnaires. Variables of measurement include the following:

(1) Responsiveness: customer service personnel immediately respond to demand and questions (Item1); customer service personnel can immediately provide the service needed (Item2); the website immediately responds to the customers' demands (Item3).

(2) Tangible: specific prices indicated on the website (Item4); specific classification of products on the websites (Item5); specific webpages on the website (Item6); specific discounts indicated on the website (Item7). 
(3) Reliability: immediate accomplishment of service on the website (Item8); precise product information for the customers (Item9); precise amount of bill after shopping (Item10).

(4) Empathy: customer service personnel can make efforts to solve the customers' problems (Item11); customer service personnel recognize the customers' needs and provide appropriate services (Item12); the customers' profits are the priority on the website (Item13); customer service personnel kindly solve the customers' problems (Item14).

(5) Guarantee: customer service personnel provide responsible service (Item15); they respond to customers' questions with sufficient professional knowledge (Item16); customer service personnel maintain certain degree of service quality (Item17); customer service personnel provide various products with consistent quality (Item18).

Hinterhuber (1998) proposed two-dimensional quality factor classification of modified Kano model, as shown in Table 1. Matzler and Hinterhuber (1998) adopts "customer satisfaction coefficients" as the criterion to improve the quality. The formula of coefficient is shown below:

C (1): Coefficient to increase customer satisfaction $=(A+O) /(A+O+M+I)$

$\mathrm{C}$ (2): Coefficient to reduce customer dissatisfaction $=(\mathrm{O}+\mathrm{M}) /(\mathrm{A}+\mathrm{O}+\mathrm{M}+\mathrm{I}) \times(-1)$

\section{Research Results}

This study obtains five "items to improve service quality" which increase customer satisfaction and reduce customer dissatisfaction (Table 2): (Item5); (Item8); (Item10); (Item17); (Item18). The results allow the online shop website to recognize the ranking of service quality items. The website can maintain good service quality of these items to result in maximum profit.

Table 2. Items to improve service quality

\begin{tabular}{|l|l|l|l|l|l|l|l|l|}
\hline Item & $A$ & $O$ & $M$ & $I$ & $R$ & $Q$ & $C(1)$ & $C(2)$ \\
\hline 1 & 10 & 19 & 4 & 9 & 0 & 3 & 0.690 & $*-0.548$ \\
\hline 2 & 20 & 10 & 5 & 4 & 1 & 5 & 0.769 & -0.385 \\
\hline 3 & 18 & 13 & 1 & 8 & 2 & 3 & 0.775 & -0.350 \\
\hline 4 & 22 & 12 & 0 & 6 & 2 & 3 & $* 0.850$ & -0.300 \\
\hline 5 & 14 & 21 & 2 & 5 & 1 & 2 & $* 0.833$ & $*-0.548$ \\
\hline 6 & 22 & 13 & 1 & 6 & 0 & 3 & $* 0.833$ & -0.333 \\
\hline 7 & 22 & 14 & 1 & 3 & 3 & 2 & $* 0.900$ & -0.375 \\
\hline
\end{tabular}




\begin{tabular}{|l|l|l|l|l|l|l|l|l|}
\hline 8 & 15 & 18 & 2 & 5 & 1 & 4 & $* 0.825$ & $*_{-} 0.500$ \\
\hline 9 & 21 & 13 & 2 & 5 & 2 & 2 & $* 0.829$ & -0.366 \\
\hline 10 & 18 & 16 & 3 & 6 & 1 & 1 & $* 0.791$ & $*_{-} 0.442$ \\
\hline 11 & 16 & 14 & 0 & 8 & 1 & 6 & $* 0.789$ & -0.368 \\
\hline 12 & 12 & 16 & 6 & 8 & 1 & 2 & 0.667 & $*_{-} 0.524$ \\
\hline 13 & 13 & 18 & 5 & 9 & 0 & 0 & 0.689 & $*_{-}-0.511$ \\
\hline 14 & 18 & 10 & 4 & 7 & 2 & 4 & 0.718 & -0.359 \\
\hline 15 & 22 & 8 & 3 & 4 & 2 & 6 & $* 0.812$ & -0.297 \\
\hline 16 & 14 & 10 & 5 & 7 & 0 & 9 & 0.667 & -0.417 \\
\hline 17 & 12 & 21 & 3 & 6 & 0 & 3 & $* 0.786$ & $*-0.571$ \\
\hline 18 & 11 & 21 & 5 & 4 & 0 & 4 & $* 0.780$ & $*-0.634$ \\
\hline Average & & & & & & $\mathbf{0 . 7 7 8}$ & $-\mathbf{0 . 4 3 5}$ \\
\hline
\end{tabular}

Note: $C$ (1): Coefficient to increase customer satisfaction $=(A+O) /(A+O+M+I)$

$C$ (2): Coefficient to reduce customer dissatisfaction $=(O+M) /(A+O+M+I) \times(-1)$

A: Attractive Quality; O: One-Dimensional Quality; M: Must-Be Quality; I: Indifferent

Quality; R: Reverse Quality; Q: undetermined

* denotes the absolute value of coefficient >absolute value of mean of overall coefficient

Source: Author.

\section{Conclusion}

The study focuses on the online shop website $\mathrm{H}$ and by Kano two-dimensional quality model, it obtains "the items to improve service quality" as the criteria for the website to improve the quality. This study acquires five "items to improve service quality" which increase customer satisfaction and reduce customer dissatisfaction: specific classification of products on the websites are immediate accomplishment of service, precise amount of bill after shopping, customer service personnel maintain certain degree of service quality, customer service personnel provide various products with consistent quality.

The website must maintain good service quality of these items to lead to competitiveness. The analytical result helps the online shop website to enhance quality and competitive advantages.

\section{References:}

Antony, J., Antony, F.J., Ghosh, S. 2004. Evaluating service quality in a UK hotel chain: a case study. International Journal of Contemporary Hospitality Management, 16, 380384.

Bateson, J.E., Hoffman, K.G. 2002. Essential of Service Marketing: Concepts, Strategy and Cases. Harcourt, Inc., NY.

Chung, Y.C., Chen, H.C. 2015. Study on the correlation among service quality, relationship 
quality and customer satisfaction-A case study of $\mathrm{H}$ hotel. International Journal of Latest Research in Science and Technology, 44(4), 1-7.

Kano, N., Seraku, N., Takahashi, F., Tsuji, S. 1984. Attractive quality and must-be quality. Hinshitsu (Quality, the Journal of Japanese Society for Quality Control), 14, 39-48.

Matzler, K., Hinterhuber, H.H. 1998. How to make product development projects more successful by integrating Kano's model of customer satisfaction into quality function deployment. Technovation, 18(1), 25-38.

Parasuraman, A., Zeithaml, V.A., Berry, L.L. 1988. SERVQUAL: a multiple-item scale for measuring consumer perception of service quality. Journal of Retailing, 64(1), 12-40.

Tsiotsou, R. 2006. The role of perceived product quality and overall satisfaction on purchase intentions. International Journal of Consumer Studies, 30(2), 207-220.

Zeithaml, V.A., Parasuraman, A., Malhotra, A. 2002. Service Quality Delivery Through Web Sites: A Critical Review of Extant Knowledge. Journal of the Academic of Marketing Science, 20(4), 362-375.

Zhang, P., Von Dran, G.M. 2001. User expectations and rankings of quality factors in different Web site domains. International Journal of Electronic Commerce, 6(2), 9-33. 